\title{
Revisioning the Pacific: Bernard Smith in the South Seas
}

European Vision and the South Pacific, 1768-1850; A Study in the History of 'Art and Ideas, by Bernard Smith.

Oxford: Clarendon, 1960. Oxford: Oxford University Press paperback, I969. New Haven: Yale University Press, 1985. Sydney: Harper \& Row, 1985. New Haven: Yale University Press, 1989. Melbourne: Oxford University Press, 1989.

Imagining the Pacific: In the IF'ake of the Cook Voyages, by Bernard Smith.

Melbourne: Melbourne University Press, 1992.

Bo R N I N Sydney in I9I6, Bernard Smith is today widely considered to be Australia's preeminent art historian and a major cultural theorist. ${ }^{1}$ While working as a school teacher and artist during the late r93os and early I940s, he came under the influences of surrealist aesthetics and communist politics, especially as mediated by refugee intellectuals from Hitler's Europe. During this period his principal literary inspirations were the Bible, Marx, and Toynbee; it was their different takes on history, especially of its unfolding over long durations, that most impressed him. ${ }^{2}$ As an academic and writer through the next half century, Smith produced numerous historically oriented studies of Australian and modernist art, which broadly can be divided into two periods of publishing activity. ${ }^{3}$ His most acclaimed achievement, however, is European Vision and the South Pacific 1768-2850: A Study in the History of Art and Ideas, first published in 1960 and a work that has continued to grow in stature and influence in the four decades since its original appearance. It is the history of this text, and of its companion-piece, Imagining the Pacific: In the Wake of the Cook Voyages, published in 1992, and the contexts in which they were produced and have been consumed, that are the main concerns of the present essay. ${ }^{4}$ 
European Vision and the South Pacific had its beginnings in Smith's very first publication, Place, Taste and Tradition: A Study of Australian Art since 2788 . The latter emerged from his early i940s work as a public arts educator, but it is equally linked to the broader context of World War II Australia, when Britain's hold on its former colony was being replaced by Australian national assertiveness and the growing influence-military, political, and cultural - of the United States. Of the shift from one text to the other, Smith noted in European Vision:

This book arose, in the first instance, from an inquiry into the origins of European art in Australia begun Is years ago and published in 1945. That inquiry revealed the need to investigate the beginnings of European art in the south Pacific more fully; beginnings which may be traced from 1768 when professional artists first began to voyage in the South Seas. How did they see this new world of the Pacific? Did their entry into it stimulate thought and affect in any way traditional forms of expression? Such questions, it seemed to me, were worth asking. (v)

Though not overtly a politicized text, Smith has since described Place, Taste and Tradition as being written from a historical materialist perspective and as having "good claim to being the first Marxist art history of a nation state." As its title indicates, "place" was a central trope in his intellectual armory from the start. However, rather than simply following the conventional interpretations of Australian art as either pale reproductions of European originals or as thoroughly local productions, his concern was the dynamic but unequal relations between Australian and European art- that is, in a wider frame, the processes of cultural exchange between metropolis and periphery. Art, like other cultural forms, Smith argued, is socially produced, quite unpredictable, invariably hybrid, and never really original, especially when cultivated in the hothouse of imperialism. If art in colonial Australia was predominately European in derivation, so too European art and thought were irretrievably affected by contacts with the Antipodes. And whereas art in Europe had often been entangled with religion, in Australia its initial reference point was science. ${ }^{6}$

Only in 1945, when the University of Sydney abandoned its insistence on Latin as a prerequisite, was Smith able to begin formal study in the humanities - specifically in undergraduate English, history, and classical archaeology. ${ }^{7}$ The following year he applied for a British Council scholarship, proposing to study "the English contribution to 
the beginnings of art in Australia"; eventually he was informed that the Courtauld Institute of Art in London would accept him for the 1948-49 year as a nonacademic student to "work on a piece of research on eighteenth- and nineteenth-century British art." ${ }^{8}$ At the Courtauld he attended courses on European art history given by, among others, Antony Blunt and E. H. Gombrich. In a lecture by the latter, he was struck by the throw-away phrase "all art is conceptual," for Smith, who until then had accepted uncritically the conventional notion of "the innocent eye," Gombrich's comment was "a revelation... [which] unwittingly provided me with a paradigm that seems to have guided my work for the next two years, though I was quite unaware of it at the time." A week later, while studying the original drawings of Parkinson and other artists who had traveled with Cook, he noted in his diary: "Considerable variation in the original sketches and the engravings made from them." It was the differences that now interested him; clearly they were not due to a lack of ability to copy accurately."

In his quest to find the work of early British artists who had traveled to Australia and in the Pacific, Smith made contact with Rex Nan Kivell, an expatriate New Zealander and connoisseur of early drawings and paintings relating to the South Seas, and R. A. Skelton, the British expert on Cook's voyages of exploration. ${ }^{10} \mathrm{He}$ also decided-since "all art is conceptual" - to start from the beginning, by looking at the earliest European ideas about the Southern Hemisphere, particularly the concept of the Antipodes. That is, a long view of history-as with the Bible, Marx, and Toynbee. Antony Blunt, director of the Courtauld, approved this project and sent Smith to the Warburg Institute to see Rudolf Wittkower, an expert on medieval teratology, who in turn endorsed Smith's direction and passed him to one of his colleagues, Charles Mitchell. Realizing that Smith's lack of Latin would prevent serious engagement with medieval notions of the Southern Hemisphere, Mitchell encouraged him to return to the art historical scholarship of the early modern period, beginning with the writings of Panofsky, and personally introduced him to Ernst Gombrich. Thus it was that Smith came back to something like his original project."

By late March 1949 the essay that was to become "European Vision and the South Pacific" was taking shape. Soon afterward, through Mitchell, a letter arrived from J. W. Davidson, a New Zealand scholar of the Pacific then based at Cambridge University - a letter which, to quote Smith, "in one sense, changed the course of my life." Davidson 
had agreed to edit a supplementary volume to accompany fellow New Zealander J. C. Beaglehole's planned three-volume Hakluyt edition of Captain Cook's journals. The supplementary (or fourth) volume would involve general essays on the historical, geographical, and ethnological aspects of the voyages; an assessment of their relation to eighteenthcentury science and philosophy; and a section on bibliographies and catalogues. Smith was invited to compile a catalogue of art from the three voyages - to be finished in a year or so. At first reluctant to take on such an unscheduled task, Smith agreed on condition that he be allowed also to write an essay on Cook's artists. But the project turned out to be much more complex than anyone had foreseen, and the intended fourth volume was eventually abandoned and replaced by Beaglehole's proposal for a biography of Cook. ${ }^{12}$ Rather than being a quickly finished bit-part to a supplementary text, Smith's allotted tasks took four decades to complete and ultimately resulted in three large volumes, The Art of Captain Cook's Voyages (1985-87), written in collaboration with Rüdiger Joppien. ${ }^{13}$

Having had his scholarship extended for another year, Smith continued his researches in the British Museum Library, The Natural History Museum, the National Maritime Museum, the Public Records Office, the Royal Commonwealth Library, the London Missionary Society headquarters, and Castle Howard in Yorkshire. The finished essay was published in the Journal of the Warburg and Courtauld Institutes in 1950. ${ }^{14}$ Little read outside of European classical and postclassical art history circles, it nevertheless laid the foundation for his influential book European $V$ ision and the South Pacific. ${ }^{15}$ Smith has recently summarized his essay as follows:

My central concern was to define the ways in which scientists made use of art to document and support their findings; and what followed from this conjunction of scientific curiosity and aesthetic vision during the late eighteenth and early nineteenth centuries. I began by looking at the instructions given to navigators on far voyages, and the degree to which the artists taken on such voyages succeeded in carrying them out. I concluded that as far as the documentation of plants, and the provision of coastal profiles as aids to navigation were concerned, the artists did succeed in providing the scientists with what they desired: faithful records of nature. 
Smith stresses this final point, noting his concern that some commentators have misinterpreted him as arguing that European depictions of un-European things are "inevitably distorted; or worse, that faithful, objective, representation of non-European places and cultures is not possible." Such misreadings of his views are dismissed by Smith as "fashionable nonsense":

What I did argue was that whenever aesthetic categories such as the picturesque, exotic, or sublime became involved they tended to affect objective description. That is to say artists, to the degree that they were artists, brought an aesthetic vision with them and applied it, sometimes consciously, sometimes unconsciously, to what they saw before them.

Such preconceptions operated most powerfully when it came to recording indigenous peoples. When Cook sailed on his first voyage a current view was that Patagonians were giants. But Banks in his descriptions, and Buchan and Parkinson, the artists he took with him, were able to correct this false notion and provide evidence that Patagonians were of normal size. Thus the enlisting of artists on scientific voyages was vindicated. ${ }^{16}$

Technically accurate drawings for scientific purpose were, however, a quite different thing from engravings produced as illustrations for aesthetically fashionable books aimed at "people of taste." Drawings by Buchan of the natives of Tierra del Fuego, for instance, were never published until Smith himself published them in $195^{\circ}$ and the I980s. Yet some of Buchan's drawings had served as the basis for illustrations by the famous English engraver Bartolozzi, who re-presented the Fuegans as "noble savages." A somewhat different transformation occurred in respect to Tahiti, where Banks had given classical Greek names to individual Tahitians based on their personal attributes. Moreover, the country itself was seen by early European visitors as an Arcadia, though the elaborate mortuary rites observed there reminded them that death was also a constant presence. In the hands of the engravers back in England, however, such considerations were translated into depictions of Tahitians in the context of the powerful trope of "death in Arcadia."

Smith's essay also contrasted the traveler's vision with those of the convict and the missionary. Thus, the Pacific, as seen by the likes of Banks, "was transformed through the eyes of the exiled convict, Thomas Watling, and the Reverend Thomas Haweis." In this way the noble sav- 
age trope-which had earlier been traced by scholars like Lovejoy and Boas back to Greek antiquity - was transformed into the trope of the ignoble savage. The latter concept, as it related to late-eighteenth- and early-nineteenth-century European art and literature, Smith insists, was very much his own invention. His essay concluded with considerations of how the missionary endeavor encouraged ideas of progress and civilization in the Pacific, and how as a result the ignoble savage was in its turn transformed into a degraded figure of fun. ${ }^{17}$

On his arrival back in Australia in early I95 1 , Smith returned to his employment in the Art Gallery of New South Wales, and the following year completed his bachelor of arts degree at Sydney University. Having resigned his membership of the Australian Communist Party prior to his departure for Britain, and given up on "real existing socialism" after a visit to Czechoslovakia, politics was no longer a significant distraction: he was now a professional art historian. ${ }^{18}$ In $1954-55$ Smith was a doctoral scholar at the Australian National University (ANU), under the supervision of J. W. Davidson, and lecturing part-time in art history at Melbourne University. Because of " $\mathrm{Mr}$ Smith's previous extensive research experience in the general field of his course, [and] his having already carried out a year's research on the margins of his $\mathrm{PhD}$ topic, as evidenced by publications," he was not required to meet the usual three years' residency requirements as a research student. The title of his thesis was "The Study of European Art and Ideas of Contact with the Pacific, I768-1851" and, on its submission in early 1956, J. C. Beaglehole (Wellington) and Charles Mitchell (London) were appointed as external examiners. ${ }^{19}$ It was, effectively, the draft manuscript for his book, European Vision and the South Pacific, $2768-2850$.

The year 1956 saw also the publication of a second important essay by Smith in the Journal of the Warburg and Courtauld Institutes. ${ }^{20}$ It radically contradicted the orthodox view of the origins of Coleridge's The Rime of the Ancient Mariner by arguing that the poem's principal inspiration had been William Wales, chief astronomer on Cook's second voyage. While researching the paintings of Hodges in the Mitchell Library, Smith had chanced upon Wales's journal manuscript and meteorological observations, and noted that after the voyage he had become mathematics teacher at Christ's Hospital, London. Knowing that Coleridge had been a pupil there around the same time, Smith surmised that Wales must have introduced him to Pacific literature and stories, a theory sub- 
stantiated by Smith's discovery of parallels between the $\log$ and the poem. ${ }^{21}$ For the next four decades, nevertheless, Coleridge scholars largely ignored this exposition of the links between Cook's greatest voyage and Coleridge's noblest work-a situation that began to change only after the essay was republished in 1992 in Smith's second major South Seas-focused work, Imagining the Pacific: In the Wake of the Cook Voyages. ${ }^{22}$ Interestingly, the Coleridge essay is the only one of the ten essays in this collection that dates specifically from the first rather than the second phase of Smith's art history career, and which is on a literary rather than a visual theme.

Broadly speaking, the essays in Imagining the Pacific are arranged chronologically, beginning with the pre-Cook period and concluding with reflections on the great explorer's posthumous reputation. Prior to the piece on Coleridge are chapters on the development in Europe of types of artwork within which "the Pacific was imaged and imagined"; the context within which "scientific" art played its subordinate but significant role in the European penetration of the Pacific; the effects of the empirical naturalism associated with travel, science, and topography on the conventions of European classical naturalism; the consequences for both Europe and the Pacific of the imposition of "an alien European genre, portraiture, upon the peoples of the Pacific"; and the impact of Pacific light and atmosphere upon the art of William Hodges, and his leading place in the history of plein-air landscape painting. Then, after the Coleridge essay, come chapters dealing with the ways an apparently "documentary art" of Pacific peoples was fashioned to serve ideological purposes; the relevance of Edward Said's notion of "orientalism" for understanding European perceptions of the Pacific; the role of the model of ancient Greece and Greek civilization in shaping the "primitivism" central to Europe's early imaginings of the Pacific; and, finally, the variety of political ends and ideological purposes "Captain James Cook" was unwittingly obliged to serve in the decades after his death.

Each of the essays in Imagining the Pacific provides a critical summary of, or an eloquent intervention in, a key thematic in the culture history of early European perceptions of the Pacific. But, equally, each develops an idea or icleas originally raised or hinted at, a third of a century earlier, in European Vision and the South Pacific. Most important, Smith's overriding concern for broad historical spans rather than specific events or epochs, for the continuities as much as the discontinuities 
of history, is mirrored in the praxis of all his writings about the South Seas. Over the years some critics have found his thinking about Australian and Western art variously too revisionist, too Marxist, too humanist, too modernist, too Hegelian. ${ }^{23}$ But such arguments lose traction when translated across to his Pacific-centered writings.

From its first publications in the I960s, European Vision and the South Pacific was welcomed by a broad audience. The paperback edition proudly highlighted a prediction from the flagship British anthropology journal Man that "students of taste, art historians, literary scholars and anthropologists... will long honour and use this book"; next to it was a quote from a review by the historian J. C. Beaglehole in the New Zealand Listener, stating that the book "really helps us, who live in the Pacific, to see our world as part of the world at large." Smith himself has said that it was mainly anthropologists and geographers, rather than art historians, who first appreciated this particular work-and there is undoubtedly a basis to his observation. But with its several re-editions during the 1980s, in both Australia and the United States, with colored illustrations and enlarged format, European Vision and the South Pacific was claimed by a fresh generation of scholars and students, many of them working in new academic fields such as postcolonial theory, travel literature, and cultural studies.

This process gained further momentum with the publication in 1992 of Imagining the Pacific. Reviews of this work were overwhelmingly positive: while it was invariably seen as a "sequel" to European Vision and the South Pacific, and lacking the dramatic impact of its predecessor, it was nevertheless considered to be a worthy and novel undertaking. ${ }^{24}$ Then in 1996 a conference was held in Canberra to honor Smith's work, and particularly "his extraordinary book European Vision and the South Pacific." In an introduction to the collection of essays that emanated from this forum, Nicholas Thomas described the latter text as having been "published twenty years too early," and as having been appreciated more by general readers than scholars "until Edward Said's Orientalism appeared in 1978 , stimulating what was to become a pervasive interest in topics such as Orientalism, primitivism, colonial culture and the representation of otherness." 25

An even more expansive summary of Smith's wide influence and ongoing relevance was provided recently by the cultural theorist John Frow, in a review of Peter Beilharz's insightful study of the man and his oeuvre: 
The central piece of work, the one that ultimately defines Smith's stature, is European Vision and the South Pacific. It is, in the first place, one of those major works of learning that transform or even establish a field of study, and its strengths lie in part in its use of the ordinary craft tools of the historian to open up an archive, to organise the vast amounts of material it contains and to develop a bold and original thesis by way of patient argument and meticulous documentation... But this history of vision has a further and broader context, that of the systematic extension of European imperialism through the Pacific in the eighteenth and nineteenth centuries, and of the structures of seeing and imagining-the categories of understanding, especially the primitivisms, hard and soft-that Europeans bring to bear in their dealings with the peoples and landscapes of the Pacific, and that they both modify and fail to modify in the process of encounter and exchange. Here Smith crucially anticipates Said's theses on Orientalism, and has had an enormously fruitful influence on histories of first contact in the Pacific. ${ }^{26}$

Bernard Smith must, therefore, be judged a revisionist in the very best senses of that word: as one who forced changes in our understanding of early contacts and interactions between Oceanic and Occidental peoples, and, especially, as the writer who initiated a seismic shift in the theorization of how and to what effect Pacific lands and their indigenous inhabitants were visually represented by early European artists and scientists in the great theater of encounter that was, and still is, the South Seas.

\section{Notes}

I. For an overview of Smith's oeuvre, see Peter Beilharz, Imagining the Antipodes: Culture Theory and the Visual in the Work of Bernard Smith (Cambridge, 1997). See also entries on Smith by Chris Wallace-Crabbe, in The Oxford Companion to Australian History, ed. Graeme Davidson, John Hirst, and Stuart Macintyre (Melbourne, I998), and by Peter Beilharz, in Dictionary of Cultural Theorists, ed. E. Cashmore and C. Rojek (New York, I999). A comprehensive intellectual biography of Smith is currently being written by Patricia Anderson.

2. Smith's early years are the focus of two finely crafted autobiographies, The Boy Adeodatus: Portrait of a Lucky Young Bastard (Ringwood, 1984), and A Pavane for Another Time (Melbourne, 2002).

3. For the first period, see especially Place, Taste and Tradition: A Study of Australian Art since 1788 (Sydney, 1945), Australian Painting, 1788-1960 (Melbourne, I962), and Bernard Smith et al., The Antipodean Manifesto: Essays in Art and History 
(Melbourne, 1959). For the second phase, see particularly The Spectre of Truganini (Sydney, 1980), Modernism's History: A Study in Twentieth Century Att and Ideas (Sydney, 1998), and Bernard Smith and A. Wheeler, eds., The Art of the First Fleet and Other Early Australian Drawings (Melbourne, 1988).

4. See also Rüdiger Joppien and Bernard Smith, The Art of Captain Cook's Voyages (vols. I-2, Sydney, 198;; vol. 3, Sydney, 1987); Andrew David with Rüdiger Joppien and Bernard Smith, The Charts and Coastal Views of Captain Cook's Voyages (vol. I, London, 1988; vol. 2, London, 1992; vol. 3, London, 1997); and W. Eisler and Bernard Smith, eds., Terra Australis: The Furthest Shore (Sydney, 1998).

5. Pavane, $124-25$.

6. Beilharz, Antipodes, chap. 2.

7. Parvane, $145-46$.

8. Ibid., $154-58$.

9. Ibid., $240-4 \mathrm{I}$.

Io. Ibid., 24 I.

II. Ibid., $245-48$.

12. Beaglehole's three edited volumes appeared between 1955 and 1967 as The Journals of Captain James Cook, while his Life of Captain James Cook was published (posthumously) in 1974 .

13. Pavane, $282-83$.

14. "European Vision and the South Pacific," Journal of the Wrarburg and Courtauld Institutes 13 (1950): 66-100.

I5. Pavane, 370-71.

16. Ibid., 371-72.

17. Ibid., 372 .

I8. Ibid., 448, 459-60.

19. Minutes of the Board of Graduate Studies, Australian National University: I8 September 1953; 26 March 1954; 20 January 1956, ANU Central Archives (thanks to Doug Munro for providing this information). See also S. G. Foster and Margaret M. Varghese, The Making of the Australian National University, 1946-8996 (Sydney, 1996), 199, 200.

20. "Coleridge's Ancient Mariner and Cook's Second Voyage," Journal of the Warburg and Courtauld Institutes i9 (1956): I17-54.

21. Bernard Smith, personal communication, 26 November 2003 ; idem, Imaging the Pacific: In the Wake of Cook's Voyages (Melbourne, 1992), $\mathrm{x}-\mathrm{xxi}$.

22. In particular, because a New Zealand-based researcher, Bill Whelan, delivered a paper on the topic at the 4 th International Coleri held in England in 2000.

23. For example, Richard Haese, Rebels and Precursors: The Revolutionary Years of Australian Art (Ringwood, 1981), I51-56; Ian Burn, Nigel Lendon, Charles Merewether, and Ann Stephen, The Necessity of Australian Art: An Essay about Interpretation (Sydney, 1988), 39-53, 62-75; Rex Butler, "Australian Art History and Revisionism," Pre/dictions: The Role of Art at the End of the Millennium (Welling- 
ton, 2000), 177--85; Fay Braeur, "Hegelian History, Wölfflinean Periodization and Smithesque Modernism," Art History 24, no. 3 (2001): 449-57. I am grateful to Deborah Cain for advice on the wider art historical contexts of Smith's career.

24. For example, reviews by Paul Carter, Journal of Historical Geography 20, no. I (1994): 8I-86; K. R. Howe, Journal of Pacific History 29, no. 2 (1994): 242; Adrienne L. Kaeppler, Eighteenth Century Studies 28, no. I (I994): 158; John Frow, UTS Review 2, no. I (1996): 182-85; Harry Liebersohn, Journal of Modern History 68 , no. 3 (1996): 617-19.

25. Nicholas Thomas and Diane Losche, eds., Double Vision: Art Histories and Colonial Histories in the Pacific (Cambridge, 1999).

26. Meanjin 56, nos. 3/4 (1997): 497-99. 